\title{
Pemberian Pupuk Silika Cair untuk Meningkatkan Pertumbuhan, Hasil, dan Toleransi Kekeringan Padi Sawah
}

\section{Application of Liquid Silica Fertilizer to Increase Growth, Yield, and Drought Tolerance in Rice}

\author{
Sugiyanta $^{1^{*}}$, I Made Dharmika², dan Dedeh Siti Mulyani² \\ ${ }^{1}$ Departemen Agronomi dan Hortikultura, Fakultas Pertanian, Institut Pertanian Bogor \\ (Bogor Agricultural University), Jl. Meranti, Kampus IPB Darmaga, Bogor 16680, Indonesia \\ ${ }^{2}$ Program Studi Agronomi dan Hortikultura, Fakultas Pertanian, Institut Pertanian Bogor, Indonesia
}

Diterima 25 April 2018/Disetujui 24 Juli 2018

\begin{abstract}
As one of the silica (Si) accumulator, rice (Oryza sativa L.) requires large amounts of silica for growth. This study aimed to determine the effect of liquid silica fertilizer application on lowland rice growth and yield, and its roles in drought stress responses. The experiments were conducted at Sawah Baru rice field and Cikabayan Greenhouse Experiment Station, IPB, Bogor during the period of January to May 2016. The field experiment was set up in a randomized complete block design with 7 treatments and three replications. The greenhouses experiment was arranged in a split-plot randomized block design with 3 replications. The main plots were 5 levels of liquid silica fertilizer application, while the subplot was 5 level of various soil water contents. The results of the field experiment showed that the application of liquid silica fertilizer increased rice shoot dry weight, total and productive tiller numbers, and yield per plant, but did not increase yield per hectare. Meanwhile at greenhouse experiment, it showed that the use of liquid silica fertilizer reduced the number of rice stomata, but did not increase cuticle thickness and grain yield per plant. Silica application was not effective to alter drought in rice.
\end{abstract}

Keywords: IPB 3S, silica fertilizer, soil water content, water use efficiency

\section{ABSTRAK}

Sebagai salah satu akumulator silika (Si), padi (Oryza sativa L.) membutuhkan sejumlah besar silika untukpertumbuhan. Penelitian ini bertujuan untuk mengetahui pengaruh pemberian pupuk silika cair pada pertumbuhan dan hasil padi sawah serta perannya dalam respon terhadap cekaman kekeringan. Percobaan dilakukan di sawah kebun percobaan Sawah Baru dan rumah kaca kebun percobaan Cikabayan, IPB, Bogor selama periode Januari hingga Mei 2016. Percobaan di sawah dilakukan dalam rancangan kelompok lengkap teracak dengan 7 perlakuan dan 3 ulangan. Percobaan di rumah kaca disusun dalam rancangan acak kelompok petak terbagi dengan 3 ulangan. Petak utama adalah 5 taraf aplikasi pupuk silika cair, sedangkan anak petak adalah 5 taraf kadar air tanah. Hasil percobaan di sawah menunjukkan bahwa aplikasi pupuk silika cair meningkatkan bobot kering tajuk, jumlah anakan total dan produktif, serta hasil per tanaman, tetapi tidak meningkatkan hasil per hektar. Hasil percobaan di rumah kaca menunjukkan bahwa penggunaan pupuk silika cair mengurangi jumlah stomata tanaman padi, tetapi tidak meningkatkan ketebalan kutikula dan hasil gabah per tanaman. Pemberian silika tidak efektif untuk mengatasi dampak kekeringan pada padi.

Kata kunci: efisiensi penggunaan air, IPB 3S, kadar air tanah, pupuk silika

\section{PENDAHULUAN}

Padi (Oryza sativa L.) merupakan salah satu tanaman akumulator silika (Si), sehingga membutuhkan silika dalam jumlah besar untuk mendukung pertumbuhannya. Tanaman padi dapat menyerap silika dalam kisaran 230$470 \mathrm{~kg} \mathrm{ha}^{-1}$ (Rao dan Susmitha, 2017). Komposisi jerami

\footnotetext{
* Penulis untuk korespondensi. e-mail: mr_sugiyanta@yahoo. co.id
}

padi terdiri atas silika $70.8 \%$, selulosa $36.5 \%$, hemiselulosa $33.8 \%$, lignin $12.3 \%$, bahan ekstraktif $3.8 \%$, dan abu $13.3 \%$ (Purwaningsih et al., 2012). Pemupukan silika penting dilakukan pada budidaya padi karena kandungan silika tersedia didalam tanah terus berkurang. Kandungan silika tersedia dalam tanah berkurang sekitar $20 \%$ pada tahun 1970-2003 (Prasetyo et al., 2010). Tanah di daerah tropis memiliki kandungan silika yang rendah karena reaksi pelapukan yang intensif, sehingga kehilangan hara (termasuk silika) tinggi (Balittanah, 2010). Rata-rata unsur silika yang diambil tanaman padi pada setiap panen sekitar 443 
$\mathrm{kg} \mathrm{ha}^{-1}$. Perpindahan unsur silika keluar areal persawahan karena terbawa hasil panen menyebabkan terjadinya proses penurunan kandungan silika tersedia dalam tanah (De Datta, 1981).

Silika tidak termasuk ke dalam unsur hara esensial bagi tanaman (Hayasaka et al., 2008), tetapi silika memberikan efek menguntungkan bagi banyak tanaman (Ashtiani et al., 2012). Silika diserap oleh tanaman dalam bentuk asam monosilikat atau asam orthanosilikat $\left(\mathrm{H}_{4} \mathrm{SiO}_{4}\right)$ (Fageria, 2014), kemudian silika ditanslokasikan melalui aliran evapotranspirasi dan dipolimerisasi serta diakumulasi pada jaringan batang dan daun sebagai silika gel $\left(\mathrm{SiO}_{2} \cdot \mathrm{nH}_{2} \mathrm{O}\right)$ (Ahmed et al., 2011). Silika adalah elemen yang bermanfaat untuk pertumbuhan tanaman dan secara agronomis penting untuk meningkatkan dan mempertahankan produktivitas padi. Selain meningkatkan hasil padi, silika juga dapat meningkatkan ketersediaan hara $(\mathrm{N}, \mathrm{P}, \mathrm{K}, \mathrm{Ca}, \mathrm{Mg}, \mathrm{S}, \mathrm{Zn})$, menurunkan toksisitas hara (Fe, Mn, P, Al), dan meminimalkan stres biotik dan abiotik pada tanaman (Rao dan Susmitha, 2017). Silika berperan dalam toleransi tanaman terhadap stres abiotik dengan meningkatkan aktivitas enzim dan metabolit antioksidan serta membantu meningkatkan efisiensi dari osmoregulator dengan mempengaruhi tingkat kandungan air, menurunkan kehilangan air dari transpirasi, mengatur kecukupan hara, dan membatasi penyerapan ion toksik (Sacala, 2009). Silika juga berperan dalam menurunkan tingkat serangan hama dan penyakit melalui dua mekanisme yaitu menjadi penghalang mekanik dan mekanisme fisiologi dalam meningkatkan resistensi terhadap hama dan penyakit (Ashtiani et al., 2012). Lapisan silika dengan ketebalan $2.5 \mu \mathrm{m}$ di bawah kutikula menghasilkan lapisan ganda kutikula-silikon yang dapat menghambat atau menunda penetrasi hama (Rodrigues dan Datnoff, 2015).

Kekurangan silika pada tanaman padi menyebabkan tanaman menjadi lebih rentan terhadap serangan serangga, penyakit jamur, dan tekanan abiotik yang berdampak buruk pada hasil dan kualitas hasil padi. Serapan silika yang rendah telah terbukti meningkatkan kerentanan tanaman padi terhadap beberapa penyakit, seperti penyakit blas, hawar daun, bintik coklat, busuk batang, dan perubahan warna bulir gabah (Ahmad et al., 2013). Pemupukan silika pada tanah sawah di Indonesia masih belum banyak dilakukan, sehingga belum banyak informasi mengenai respon pemupukan silika terhadap pertumbuhan dan hasil tanaman padi. Informasi mengenai sumber unsur silika juga masih terbatas. Penelitian ini bertujuan untuk mengetahui peran pupuk silika terhadap pertumbuhan, hasil, dan toleransi terhadap kekeringan pada padi sawah.

\section{BAHAN DAN METODE}

\section{Bahan Tanaman dan Alat}

Bahan yang digunakan dalam penelitian ini adalah benih padi varietas IPB $3 \mathrm{~S}$, pupuk silika cair dengan kandungan Si $2.5 \%$ m/v, pupuk NPK 15-15-15, dan pupuk
Urea. Alat yang digunakan adalah oven untuk mengukur bobot kering tanah dan biomassa tanaman, timbangan analitik, mikroskop elektrik trinokuler dengan software DP2BSW dan kamera digital Olympus DP25 untuk mengamati jumlah stomata dan ketebalan kutikula, ember kapasitas $10 \mathrm{~L}$ sebagai pot perlakuan, ohm meter untuk mengukur kadar air tanah, dan tensiometer untuk mengukur kadar air kapasitas lapang. Kalibrasi alat ohm meter dilakukan dengan cara menancapkan elektroda yang terhubung ke ohm meter pada tanah kering angin yang sudah diberi air hingga jenuh. Nilai yang tertera pada ohm meter $(\mathrm{X})$ kemudian dibuat hubungan antara $\mathrm{X}$ dan $\mathrm{Y}$ dengan nilai kadar air tanah secara gravimetri (Y). Penentuan nilai kadar air dengan metode gravimetri melalui persamaan:

$$
\theta \mathrm{g}=\frac{\text { (Bobot basah-Bobot kering) }}{\text { Bobot kering }} \times 100 \% \text {. }
$$

Bobot kering diperoleh dari bobot kering oven dengan suhu $105{ }^{\circ} \mathrm{C}$ sampai diperoleh bobot konstan. Kalibrasi alat tensiometer dilakukan dengan cara menancapkan tensiometer pada tanah kering angin yang sudah diberi air hingga jenuh. Nilai yang tertera pada tensiometer dihubungkan dengan nilai kapasitas lapang yang didapat dari persamaan:

$=\frac{\text { Bobot basah tanah pada kapasitas lapang-bobot kering) }}{\text { Bobot kering }} \times 100 \%$.

Kadar air kapasitas lapang terjadi pada potensial air tanah sebesar $-0.3 \mathrm{kPa}$.

\section{Percobaan di Lapang: Pengaruh Silika Cair terhadap Pertumbuhan dan Hasil Padi Sawah}

Percobaan dilaksanakan di Kebun Percobaan IPB Sawah Baru, Bogor. Analisis kandungan silika dalam tanah, jerami, dan gabah dilakukan di Laboratorium Pengujian Departemen Agronomi dan Hortikultura, IPB. Percobaan dilakukan dari bulan Januari hingga bulan Mei 2016. Rancangan yang digunakan yaitu rancangan acak kelompok lengkap teracak dengan 7 perlakuan pupuk silika cair yaitu kontrol (tanpa pupuk silika cair), 1.0 $\mathrm{L} \mathrm{ha}^{-1}, 2.0 \mathrm{~L} \mathrm{ha}^{-1}, 3.0$ $\mathrm{L} \mathrm{ha}^{-1}, 4.0 \mathrm{~L} \mathrm{ha}^{-1}, 5.0 \mathrm{~L} \mathrm{ha}^{-1}$, dan $6.0 \mathrm{~L} \mathrm{ha}^{-1}$ pupuk silika cair. Tiap perlakuan diulang sebanyak tiga kali, dengan demikian terdapat 21 satuan percobaan. Setiap petak percobaan berukuran $25 \mathrm{~m}^{2}$. Bibit padi varietas IPB 3S yang digunakan berumur 14 hari dan jarak tanam yang digunakan $30 \mathrm{~cm} \times 15 \mathrm{~cm}$ dengan 5 bibit per lubang tanam. Pupuk silika cair diaplikasikan 2 kali yaitu pada 15 dan 30 hari setelah tanam dengan cara disemprot. Pupuk dasar yang diberikan yaitu $90 \mathrm{~kg} \mathrm{~N} \mathrm{ha-1,} 45 \mathrm{~kg} \mathrm{P}_{2} \mathrm{O}_{5} \mathrm{ha}^{-1}$, dan $45 \mathrm{~kg}$ $\mathrm{K}_{2} \mathrm{O}$ ha $^{-1}$ yang diaplikasikan pada 1 dan 4 minggu setelah tanam (MST). Pengamatan yang dilakukan meliputi analisis kandungan silika total dalam tanah sebelum percobaan, silika dalam jerami dan gabah saat panen (menggunakan metode Gravimetri (Balittanah, 2009), tinggi tanaman, jumlah anakan, bobot kering tajuk, sudut daun bendera yang diukur dengan busur derajat, hasil gabah basah dan kering per tanaman, Gabah Kering Panen (GKP) dan Gabah Kering Giling (GKG) yang dikonversi dari hasil ubinan. 
Percobaan di Rumah Kaca: Pengaruh Silika Cair terhadap Cekaman Kekeringan

Percobaan dilaksanakan di rumah kaca Kebun Percobaan IPB Cikabayan, Bogor. Pengamatan jumlah stomata dan ketebalan kutikula dilakukan di Laboratorium Mikroteknik Departemen Agronomi dan Hortikultura, IPB. Rancangan percobaan yang digunakan adalah split plot dengan dua faktor yaitu pupuk silika cair sebagai petak utama dan kadar air tanah sebagai anak petak. Perlakuan pupuk silika cair terdiri atas 5 taraf yaitu kontrol (tanpa pupuk silika cair), konsentrasi $0.5 \mathrm{~mL} \mathrm{~L}^{-1}, 1 \mathrm{~mL} \mathrm{~L}^{-1}, 1.5$ $\mathrm{mL} \mathrm{L}{ }^{-1}$, dan $2 \mathrm{~mL} \mathrm{~L}^{-1}$. Perlakuan kadar air tanah terdiri atas 5 taraf yaitu genangan $3 \mathrm{~cm}$, kadar air jenuh, 100\% kapasitas lapang, 75\% kapasitas lapang, dan 50\% kapasitas lapang. Tanah yang digunakan sebagai media tanam dikeringanginkan selama 1-2 minggu. Tanah yang sudah dikeringkan, dihaluskan dan diayak kemudian dimasukkan ke ember sebanyak $7 \mathrm{~kg}$ untuk setiap pot perlakuan. Setiap perlakuan diulang 3 kali dan satu satuan percobaan terdiri dari 4 pot. Setiap pot ditanam 3 bibit padi berumur 14 hari.

Pupuk yang digunakan yaitu $112.5 \mathrm{~kg} \mathrm{~N} \mathrm{ha}^{-1}, 45 \mathrm{~kg}$ $\mathrm{P}_{2} \mathrm{O}_{5}$ ha $^{-1}$, dan $45 \mathrm{~kg} \mathrm{~K}_{2} \mathrm{O} \mathrm{ha}^{-1}$ yang diaplikasikan tiga kali pada 1, 3, dan 5 MST. Aplikasi pupuk silika cair dilakukan pada saat 2, 4, 6, 8 MST dengan volume semprot 171.5 $\mathrm{mL}$ per tanaman. Perlakuan kadar air dimulai pada saat transplanting. Peubah yang diamati yaitu jumlah stomata dan ketebalan kutikula (diamati pada 6, 8, 10, dan 12 MST), evapotranspirasi, water use efficiency (WUE), dan produksi gabah per tanaman. Pengukuran evapotranspirasi (ET) adalah dengan terlebih dahulu mengetahui volume air tanah dalam pot $\left(\mathrm{V}_{0}\right)=\mathrm{S}_{1}-\mathrm{P}_{1} \cdot \mathrm{S}_{1}$ adalah volume air pada penyiraman pertama dan $\mathrm{P}_{1}$ adalah volume air perkolasi pada saat penyiraman pertama. Evapotranspirasi pertama $\left(\mathrm{ET}_{1}\right)$ dapat diketahui pada penyiraman 2-3 hari berikutnya dengan perhitungan $\mathrm{V}_{0}-\left(\mathrm{S}_{2}-\mathrm{P}_{2}\right)$. ET $\mathrm{T}_{\mathrm{n}}$ berikutnya diketahui dengan perhitungan $\mathrm{V}_{0}-\left(\mathrm{S}_{\mathrm{n}}-\mathrm{P}_{\mathrm{n}}\right)$ dan seterusnya, sehingga didapat ET total sampai panen (Efendi dan Azrai, 2010). Efisiensi penggunaan air (water use efficiency) dihitung berdasarkan nisbah produksi gabah (kadar air 14\%) dengan nilai evapotranspirasi.

\section{Analisis Data}

Data hasil pengamatan dianalisis dengan menggunakan uji F (analisis sidik ragam). Apabila hasil uji F nyata, maka dilanjutkan dengan uji jarak berganda Duncan (Duncan Multiple Range Test/DMRT) pada taraf $5 \%$. Data analisis kandungan silika dalam tanah, jerami, dan gabah dianalisis secara komposit sehingga tidak dianalisis secara statistika.

\section{HASIL DAN PEMBAHASAN}

\section{Percobaan di Lapang}

\section{Analisis Kandungan Silika Total dalam Tanah, Jerami, dan Gabah}

Hasil analisis kandungan silika total dalam tanah pada awal percobaan sebesar $1.11 \%$ (22.2 ton ha $\left.^{-1}\right)$. Ratarata kandungan silika total dalam tanah pada perlakuan 1-6 $\mathrm{L} \mathrm{ha}^{-1}$ pupuk silika cair sekitar $0.58-0.86 \%$ (11.6-17.2 ton $\mathrm{ha}^{-1}$ ), sedangkan kandungan silika total pada perlakuan kontrol setelah percobaan sekitar $0.61 \%$ (12.2 ton $\mathrm{ha}^{-1}$ ). Kandungan silika total dalam tanah setelah percobaan mengalami penurunan sekitar 29.1-91.4 \% dibandingkan kandungan silika total dalam tanah pada awal percobaan (Tabel 1). Penurunan silika dalam tanah diduga karena dinamika silika di dalam tanah. Hal tersebut terlihat dari kandungan silika pada perlakuan kontrol setelah percobaan juga mengalami penurunan mendekati kandungan silika total pada perlakuan pupuk silika cair. Beberapa faktor yang mempengaruhi kandungan silika dalam tanah yaitu pelapukan, $\mathrm{pH}$ tanah, kehadiran aluminium dan oksidasi besi, interaksi dengan logam berat $(\mathrm{Cd}, \mathrm{Pb}, \mathrm{Zn}, \mathrm{Hg})$, serta interaksi dengan fosfat (Lindsay, 1979; Matichenkov dan Bocharnikova, 2001). Asam silikat $\left(\mathrm{H}_{4} \mathrm{SiO}_{4}\right)$ lebih mudah larut dan lebih kecil kemungkinannya untuk berdisosiasi pada $\mathrm{pH}$ rendah (Lindsay, 1979).

Tabel 1. Hasil analisis tanah, jerami, dan gabah

\begin{tabular}{|c|c|c|c|c|c|c|}
\hline \multirow{2}{*}{ Perlakuan } & \multicolumn{2}{|c|}{ Kandungan Si dalam tanah } & \multicolumn{2}{|c|}{ Kandungan Si dalam jerami } & \multicolumn{2}{|c|}{ Kandungan Si dalam gabah } \\
\hline & $\%$ & ton $\mathrm{ha}^{-1}$ & $\%$ & ton $\mathrm{ha}^{-1}$ & $\%$ & ton $\mathrm{ha}^{-1}$ \\
\hline Sebelum perlakuan & 1.11 & 22.2 & & & & \\
\hline \multicolumn{7}{|l|}{ Setelah perlakuan } \\
\hline Kontrol & 0.61 & 12.2 & 15.7 & 4.2 & 14.3 & 0.40 \\
\hline $1 \mathrm{~L} \mathrm{ha}^{-1}$ silika cair & 0.81 & 16.2 & 17.6 & 6.2 & 8.0 & 0.26 \\
\hline $2 \mathrm{~L} \mathrm{ha}^{-1}$ silika cair & 0.77 & 15.4 & 17.0 & 5.8 & 11.3 & 0.33 \\
\hline $3 \mathrm{~L} \mathrm{ha}^{-1}$ silika cair & 0.58 & 11.6 & 21.2 & 5.7 & 9.6 & 0.31 \\
\hline $4 \mathrm{~L} \mathrm{ha}^{-1}$ silika cair & 0.75 & 15.0 & 17.6 & 7.5 & 17.6 & 0.51 \\
\hline $5 \mathrm{~L} \mathrm{ha}^{-1}$ silika cair & 0.66 & 13.2 & 15.7 & 5.0 & 9.4 & 0.26 \\
\hline $6 \mathrm{~L} \mathrm{ha}^{-1}$ silika cair & 0.86 & 17.2 & 12.6 & 5.0 & 9.3 & 0.29 \\
\hline
\end{tabular}

Keterangan: Nilai tidak dianalisis statistik 
Hasil analisis kandungan silika dalam jerami dan gabah menunjukkan bahwa kandungan silika dalam tanaman (jerami dan gabah) pada perlakuan 1-6 $\mathrm{L} \mathrm{ha}^{-1}$ silika cair lebih tinggi dibandingkan perlakuan kontrol. Kandungan silika dalam tanaman pada perlakuan kontrol hanya sekitar 4.60 ton ha $^{-1}$, sedangkan kandungan silika dalam tanaman pada perlakuan 1-6 $\mathrm{L} \mathrm{ha}^{-1}$ silika cair sekitar 5.26-8.01 ton $\mathrm{ha}^{-1}$ (Tabel 1). Hal tersebut menunjukkan aplikasi 1-6 L ha-1 silika cair dapat meningkatkan ketersediaan silika pada tanaman padi sawah. Meningkatnya serapan silika pada perlakuan penyemprotan pupuk silika cair karena bagian apoplas daun dapat menyerap silika. Sel daun mengambil unsur silika dari apoplas (Matlou, 2006).

\section{Peran Pupuk Silika Cair terhadap Pertumbuhan Tanaman}

Aplikasi pupuk silika cair tidak memberikan pengaruh yang nyata terhadap tinggi tanaman padi sawah varietas IPB $3 \mathrm{~S}$ pada $3,5,6$, dan $7 \mathrm{MST}$, tetapi perlakuan $6 \mathrm{~L}$ ha $^{-1}$ silika cair nyata meningkatkan tinggi tanaman pada 4 MST (Tabel 2). Hal tersebut diduga karena silika tidak memberikan pengaruh langsung terhadap pertumbuhan tanaman. Menurut Wang et al. (2014), aplikasi silika tidak berpengaruh langsung terhadap pertumbuhan tanaman, tetapi dapat mengontrol cekaman abiotik dan biotik seperti kekeringan dan serangan hama penyakit. Ghanbari dan Malidareh (2011) menambahkan bahwa silika hanya memiliki sedikit pengaruh pada tahap vegetatif.

Pupuk silika cair terlihat dapat meningkatkan jumlah anakan padi pada 5, 6 dan 7 MST. Rata-rata jumlah anakan yang dihasilkan perlakuan 1-6 $\mathrm{L} \mathrm{ha}^{-1}$ pupuk silika cair pada 7 MST sekitar 12-15 anakan, sedangkan perlakuan kontrol hanya menghasilkan sekitar 10 anakan. Rata-rata anakan paling banyak dihasilkan oleh perlakuan pupuk silika cair dengan dosis 5.0 $\mathrm{L} \mathrm{ha}^{-1}$ yaitu sebanyak 16 anakan (Tabel 3). Yohana (2013) menyatakan bahwa akumulasi asimilat selama proses fotosintesis dapat meningkatkan jumlah anakan. Keberadaan silika dapat menggiatkan pembentukan anakan yang ditentukan oleh kegiatan pembelahan sel. Hasil penelitian Zulputra et al. (2014) menunjukkan bahwa jumlah anakan padi meningkat dengan meningkatnya serapan $\mathrm{P}$ akibat pemberian silika karena fosfor dibutuhkan tanaman dalam proses pembelahan sel dan sebagai energi dalam setiap proses metabolisme tanaman.

\section{Peran Pupuk Silika terhadap Bobot Kering Akar dan Tajuk}

Aplikasi 1-6 $\mathrm{L} \mathrm{ha}^{-1}$ pupuk silika cair dengan cara disemprotkan ke tajuk tidak berpengaruh nyata terhadap bobot kering akar. Rata-rata bobot kering akar yang

Tabel 2. Pengaruh pupuk silika cair terhadap tinggi tanaman

\begin{tabular}{lclcrc}
\hline $\begin{array}{l}\text { Dosis aplikasi } \\
\text { silika }\left(\mathrm{L} \mathrm{ha}^{-1}\right)\end{array}$ & \multicolumn{5}{c}{ Tinggi tanaman $(\mathrm{cm})$} \\
\cline { 2 - 6 } & $3 \mathrm{MST}$ & $4 \mathrm{MST}$ & $5 \mathrm{MST}$ & $6 \mathrm{MST}$ & $7 \mathrm{MST}$ \\
\hline 0 (Kontrol) & 51.9 & $69.4 \mathrm{bcd}$ & 84.9 & 95.9 & 108.1 \\
1 & 52.6 & $73.2 \mathrm{abc}$ & 87.0 & 101.9 & 111.2 \\
2 & 49.3 & $70.3 \mathrm{bcd}$ & 86.3 & 105.5 & 110.1 \\
3 & 53.1 & $73.1 \mathrm{abc}$ & 86.0 & 100.8 & 109.8 \\
4 & 49.8 & $69.1 \mathrm{bcd}$ & 83.2 & 94.4 & 109.0 \\
5 & 48.2 & $65.7 \mathrm{~d}$ & 81.4 & 102.5 & 107.6 \\
6 & 51.6 & $74.1 \mathrm{a}$ & 90.7 & 97.5 & 111.2 \\
\hline
\end{tabular}

Keterangan: tidak terdapat perbedaan yang nyata antar perlakuan berdasarkan uji $\mathrm{F}$ taraf $5 \%$

Tabel 3. Pengaruh pupuk silika terhadap jumlah anakan

\begin{tabular}{lccccc}
\hline $\begin{array}{l}\text { Dosis aplikasi } \\
\text { silika }\left(\mathrm{L} \mathrm{ha}^{-1}\right)\end{array}$ & \multicolumn{5}{c}{ Jumlah anakan } \\
\cline { 2 - 5 } 0 (Kontrol) & $3 \mathrm{MST}$ & $4 \mathrm{MST}$ & $5 \mathrm{MST}$ & $6 \mathrm{MST}$ & $7 \mathrm{MST}$ \\
1 & 10.6 & 10.0 & $11.1 \mathrm{c}$ & $11.3 \mathrm{c}$ & $9.9 \mathrm{c}$ \\
2 & 11.4 & 12.3 & $14.7 \mathrm{ab}$ & $16.4 \mathrm{a}$ & $14.1 \mathrm{ab}$ \\
3 & 10.6 & 12.3 & $15.3 \mathrm{ab}$ & $15.9 \mathrm{ab}$ & $14.9 \mathrm{ab}$ \\
4 & 10.3 & 11.3 & $14.3 \mathrm{~b}$ & $13.7 \mathrm{abc}$ & $14.6 \mathrm{ab}$ \\
5 & 9.1 & 9.6 & $12.8 \mathrm{bc}$ & $13.1 \mathrm{bc}$ & $13.3 \mathrm{ab}$ \\
6 & 9.9 & 11.9 & $16.1 \mathrm{a}$ & $15.8 \mathrm{ab}$ & $15.2 \mathrm{a}$ \\
\hline
\end{tabular}

Keterangan: Angka-angka pada kolom yang sama yang diikuti huruf yang sama tidak berbeda nyata menurut uji Duncan's mutiple range test (DMRT) taraf $\alpha 5 \%$ 
dihasilkan perlakuan 1-6 $\mathrm{Lha}^{-1}$ sekitar 33.4-53.2 g, sedangkan perlakuan kontrol menghasilkan 33.9 g. Aplikasi 4 dan 6 $\mathrm{L} \mathrm{ha}^{-1}$ pupuk silika cair nyata meningkatkan bobot kering tajuk tanaman padi. Perlakuan $4 \mathrm{~L} \mathrm{ha}^{-1}$ pupuk silika cair menghasilkan rata-rata bobot kering tajuk terbesar (138.8 g), sedangkan perlakuan kontrol menghasilkan rata-rata bobot kering tajuk terendah (86.4 g) (Gambar 1). Menurut Gerami et al. (2012), silika yang terakumulasi bersama lignin pada dinding sel dapat meningkatkan bobot kering tajuk. Epstein (2009) menambahkan bahwa silika dapat meningkatkan laju fotosintesis dan mencegah kerusakan klorofil sehingga menghasilkan lebih banyak fotosintat. Hal tersebut menyebabkan pertambahan berat kering tajuk.

\section{Peran Pupuk Silika Cair terhadap Sudut Daun Bendera dan Hasil}

Pengukuran sudut daun bendera bertujuan untuk melihat ketegakan daun bendera. Perlakuan 1-6 L ha ${ }^{-1}$ pupuk silika cair tidak memberikan pengaruh yang nyata terhadap sudut daun bendera. Meskipun demikian, perlakuan kontrol (tanpa pupuk silika cair) memiliki rata-rata sudut daun bendera paling besar sekitar $27.7^{\circ}$, sedangkan ratarata sudut daun bendera pada perlakuan 1-6 $\mathrm{L} \mathrm{ha}^{-1}$ pupuk silika cair sekitar 21.1-27.0 (Tabel 4). Junior et al. (2010) menyatakan bahwa aplikasi silika mengakibatkan sudut daun menjadi lebih tegak. Sudut daun yang tegak menyebabkan daun lebih efektif dalam penyerapan cahaya matahari, sehingga aktivitas fotosintesis meningkat. Lu et al. (2010) menambahkan bahwa struktur kanopi mempengaruhi hasil tanaman. Hasil penelitian Wahyuti et al. (2013) menunjukkan bahwa tingginya hasil tanaman padi berkorelasi negatif dengan karakter sudut tiga daun bagian atas.

Aplikasi pupuk silika cair nyata meningkatkan hasil gabah basah dan kering per tanaman (Tabel 4). Perlakuan $3 \mathrm{~L} \mathrm{ha}^{-1}$ pupuk silika cair nyata menghasilkan hasil gabah basah dan kering per tanaman tertinggi. Rata-rata hasil gabah basah dan kering per tanaman yang dihasilkan perlakuan $3 \mathrm{~L} \mathrm{ha}^{-1}$ pupuk silika cair sekitar $36.4 \mathrm{~g}$ dan $29.4 \mathrm{~g}$ (Tabel 4). Salah satu peran silika yaitu meningkatkan efisiensi fotosintesis sehingga produksi tanaman dapat meningkat (Prasetyo et al., 2010).

\section{Percobaan di Rumah Kaca}

Percobaan di rumah kaca bertujuan untuk mengetahui peran pupuk silika cair terhadap cekaman kekeringan. Pengaruh pemberian silika cair terhadap toleransi pada cekaman kekeringan dilihat dari kriteria water use efficiency (WUE). Jumlah stomata yang dihasilkan perlakuan 0.5-2 $\mathrm{ml} \mathrm{L}^{-1}$ pupuk silika cair nyata lebih sedikit dibandingkan perlakuan kontrol pada 6, 8, dan 10 MST. Perlakuan 0.5-2 $\mathrm{mL} \mathrm{L}^{-1}$ menghasilkan sekitar 40-42 stomata pada $6 \mathrm{MST}$, 46-52 stomata pada 8 MST, dan 55-57 stomata pada 10 MST, sedangkan perlakuan kontrol menghasilkan sekitar 55 stomata pada $6 \mathrm{MST}$, 66 stomata pada $8 \mathrm{MST}$, dan 71 stomata

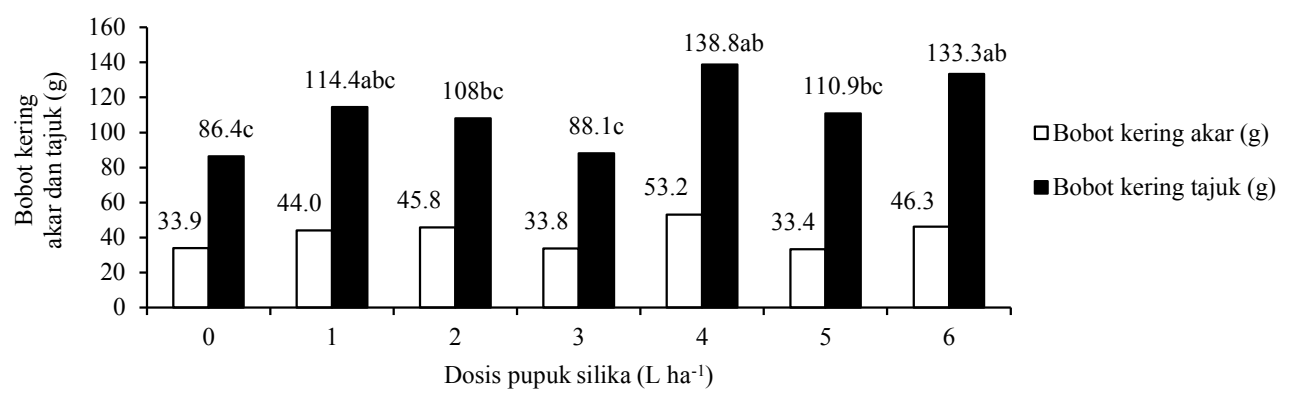

Gambar 1. Pengaruh aplikasi pupuk silika cair terhadap bobot kering akar dan tajuk

Tabel 4. Pengaruh aplikasi pupuk silika terhadap sudut daun, dan bobot kering tajuk

\begin{tabular}{lccccc}
\hline $\begin{array}{l}\text { Dosis aplikasi } \\
\text { silika }\left(\mathrm{L} \mathrm{ha}^{-1}\right)\end{array}$ & $\begin{array}{c}\text { Sudut daun } \\
\text { bendera }\left({ }^{\circ}\right)\end{array}$ & $\begin{array}{c}\text { Hasil gabah basah } \\
\text { per tanaman }(\mathrm{g})\end{array}$ & $\begin{array}{c}\text { Hasil gabah kering } \\
\text { per tanaman }(\mathrm{g})\end{array}$ & $\begin{array}{c}\text { GKP } \\
\left(\text { ton ha }^{-1}\right)\end{array}$ & $\begin{array}{c}\text { GKG } \\
(\text { ton ha }\end{array}$
\end{tabular}

Keterangan: Angka-angka pada kolom yang sama yang diikuti huruf yang sama tidak berbeda nyata menurut uji Duncan's mutiple range test (DMRT) taraf $\alpha 5 \%$ 
pada 10 MST (Tabel 5). Arista et al. (2015) menyatakan bahwa silika memiliki kemampuan untuk menekan laju transpirasi. Silika dapat mengurangi jumlah stomata untuk mengurangi laju transpirasi.

Pupuk silika cair tidak efektif meningkatkan ketebalan kutikula tanaman padi. Perlakuan kontrol memiliki kutikula yang lebih tebal(4768.6 nm) dibandingkan seluruh perlakuan pupuk silika cair pada 6 MST(3415.8-3821.2 nm), sedangkan pada 8,9 , dan 10 MST ketebalan kutikula perlakuan pupuk silika cair tidak berbeda nyata dengan perlakuan kontrol (Tabel 6). Aplikasi pupuk silika cair nyata menurunkan jumlah stomata tetapi tidak efektif meningkatkan efisiensi penggunaan air (WUE) pada beberapa tingkat kadar air tanah (Tabel 7). Data produksi gabah per rumpun di rumah kaca terlihat jauh lebih kecil dibanding hasil di lapangan. Hal ini karena kondisi iklim mikro dan media tumbuh yang jauh berbeda (Tabel 7).

Tabel 5. Pengaruh pupuk silika dan kadar air terhadap jumlah stomata

\begin{tabular}{|c|c|c|c|c|}
\hline \multirow{2}{*}{ Perlakuan } & \multicolumn{4}{|c|}{ Umur tanaman (MST) } \\
\hline & 6 & 8 & 10 & 12 \\
\hline \multicolumn{5}{|l|}{ Konsentrasi silika } \\
\hline Kontrol & $54.8 \mathrm{a}$ & $65.5 \mathrm{a}$ & $71.3 \mathrm{a}$ & 76.6 \\
\hline $0.5 \mathrm{~mL} \mathrm{~L}^{-1}$ & $39.5 b$ & $47.4 \mathrm{~b}$ & $57.3 \mathrm{~b}$ & 71.7 \\
\hline $1.0 \mathrm{~mL} \mathrm{~L}^{-1}$ & $43,3 b$ & $52.3 b$ & $54.9 b$ & 69.9 \\
\hline $1.5 \mathrm{~mL} \mathrm{~L}^{-1}$ & $42.4 b$ & $46.2 b$ & $55.5 b$ & 72.9 \\
\hline $2.0 \mathrm{~mL} \mathrm{~L}^{-1}$ & $43.5 b$ & $46.8 \mathrm{~b}$ & $54.8 b$ & 68.5 \\
\hline \multicolumn{5}{|l|}{ Kadar air } \\
\hline Tergenang $3 \mathrm{~cm}$ & 49.9 & 53.5 & 58.1 & 73.9 \\
\hline Jenuh & 46.2 & 52.5 & 58.8 & 75.4 \\
\hline $100 \%$ & 47.5 & 50.5 & 55.6 & 74.1 \\
\hline $75 \%$ & 45.0 & 53.9 & 61.7 & 67.3 \\
\hline $50 \%$ & 42.3 & 49.5 & 60.8 & 67.2 \\
\hline Interaksi & tn & tn & tn & tn \\
\hline
\end{tabular}

Keterangan: Angka-angka yang diikuti oleh huruf yang sama pada perlakuan dan kolom yang sama tidak berbeda nyata berdasarkan uji DMRT taraf $\alpha 5 \%$

Tabel 6. Pengaruh pupuk silika cair dan kadar air terhadap ketebalan kutikula

\begin{tabular}{|c|c|c|c|c|}
\hline \multirow{2}{*}{ Perlakuan } & \multicolumn{4}{|c|}{ Umur tanaman (MST) } \\
\hline & 6 & 8 & 10 & 12 \\
\hline & 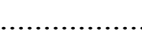 & ......nm....... & ................ & \\
\hline \multicolumn{5}{|l|}{ Konsentrasi silika } \\
\hline Kontrol & $4,768.6 \mathrm{a}$ & $4,891.0 \mathrm{a}$ & $5,246.1$ & $6,207.8$ \\
\hline $0.5 \mathrm{~mL} \mathrm{~L}^{-1}$ & $3,779.3 b$ & $3,949.0 \mathrm{ab}$ & $5,120.6$ & $6,011.3$ \\
\hline $1.0 \mathrm{~mL} \mathrm{~L}^{-1}$ & $3,821.2 b$ & $4,477.2 \mathrm{ab}$ & $5,440.6$ & $6,121.0$ \\
\hline $1.5 \mathrm{~mL} \mathrm{~L}^{-1}$ & $3,415.8 b$ & $4,714.5 \mathrm{a}$ & $5,346.0$ & $6,097.7$ \\
\hline $2.0 \mathrm{~mL} \mathrm{~L}^{-1}$ & $3,786.5 b$ & $4,369.8 \mathrm{ab}$ & $5,169.6$ & $6,053.5$ \\
\hline \multicolumn{5}{|l|}{ Kadar air } \\
\hline Tergenang $3 \mathrm{~cm}$ & $4,199.6$ & $4,213.3 b$ & $5,235.9$ & $5,972.8$ \\
\hline Jenuh & $3,954.1$ & $4,162.5 b$ & $5,040.1$ & $6,520.3$ \\
\hline $100 \%$ & $4,040.8$ & $4,784.2 \mathrm{ab}$ & $5,235.9$ & $5,849.4$ \\
\hline $75 \%$ & $3,929.7$ & $4,240.6 b$ & $5,345.6$ & $6,100.1$ \\
\hline $50 \%$ & $3,514.5$ & $5,007.9 \mathrm{a}$ & $5,488.1$ & $6,005.4$ \\
\hline Interaksi & $\operatorname{tn}$ & tn & $\operatorname{tn}$ & th \\
\hline
\end{tabular}

Keterangan: Angka-angka yang diikuti oleh huruf yang sama pada perlakuan dan kolom yang sama tidak berbeda nyata berdasarkan uji DMRT taraf $\alpha 5 \%$ 
Tabel 7. Pengaruh pupuk silika cair dan kadar air terhadap produksi gabah per rumpun, evapotranspirasi, dan efisiensi penggunaan air (water use efficiency/WUE)

\begin{tabular}{lccc}
\hline Perlakuan & $\begin{array}{c}\text { Produksi gabah per rumpun } \\
(\mathrm{g})\end{array}$ & $\begin{array}{c}\text { Evapotranspirasi } \\
\text { (liter per rumpun })\end{array}$ & $\begin{array}{c}\text { Efisiensi penggunaan air } \\
\left(\mathrm{g} \mathrm{L}^{-1}\right)\end{array}$ \\
\hline Konsentrasi silika & 1.8 & $8.2 \mathrm{~b}$ & 0.13 \\
Kontrol & 3.5 & $31.5 \mathrm{a}$ & 0.07 \\
$0.5 \mathrm{~mL} \mathrm{~L}^{-1}$ & 2.6 & $21.7 \mathrm{a}$ & 0.08 \\
$1.0 \mathrm{~mL} \mathrm{~L}^{-1}$ & 2.3 & $20.4 \mathrm{ab}$ & 0.05 \\
$1.5 \mathrm{~mL} \mathrm{~L}^{-1}$ & 2.2 & $20.7 \mathrm{ab}$ & 0.06 \\
$2.0 \mathrm{~mL} \mathrm{~L}^{-1}$ & & & $0.08 \mathrm{ab}$ \\
Kadar air & $3.7 \mathrm{ab}$ & $52.9 \mathrm{a}$ & $0.18 \mathrm{a}$ \\
Tergenang $3 \mathrm{~cm}$ & $4.5 \mathrm{a}$ & $19.0 \mathrm{~b}$ & $0.04 \mathrm{ab}$ \\
Jenuh & $1.0 \mathrm{~b}$ & $18.4 \mathrm{~b}$ & $0.04 \mathrm{ab}$ \\
$100 \%$ & $0.6 \mathrm{~b}$ & $10.3 \mathrm{bc}$ & $0.02 \mathrm{~b}$ \\
$75 \%$ & $0.6 \mathrm{~b}$ & $1.7 \mathrm{c}$ & tn \\
$50 \%$ & th & th & \\
\hline Interaksi & & & \\
\hline
\end{tabular}

Keterangan: Angka-angka yang diikuti oleh huruf yang sama pada perlakuan dan kolom yang sama tidak berbeda nyata berdasarkan uji DMRT taraf $\alpha 5 \%$

\section{KESIMPULAN}

Aplikasi pupuk silika cair di lapangan meningkatkan jumlah anakan, bobot kering tajuk, hasil gabah basah dan kering per tanaman. Aplikasi $3 \mathrm{~L} \mathrm{ha}^{-1}$ pupuk silika cair meningkatkan $21.3 \%$ hasil gabah basah per tanaman dan $20.0 \%$ hasil gabah kering per tanaman. Aplikasi pupuk silika cair pada percobaan di rumah kaca nyata mengurangi jumlah stomata, tetapi tidak meningkatkan efisiensi penggunaan air (WUE) pada beberapa taraf kadar air tanah dan tidak meningkatkan toleransi padi terhadap kekeringan.

\section{DAFTAR PUSTAKA}

Ahmad, A., M. Afzal, A.U.H. Ahmad, M. Tahir. 2013. Effect of foliar application of silicon on yield and quality of rice (Oryza sativa L.). Cercetari Agron. Moldova $46: 155$.

Ahmed, M., F. Hassen, U. Qadeer, M.A. Aslam. 2011. Silicon application and drought tolerance mechanism of sorghum. Afr. J. Agric. Res. 6:594-607.

Arista Y., K.A. Wijaya, Slameto. 2015. Morfologi dan fisiologi dua varietas tebu (Saccharum officinarum L.) sebagai respon pemupukan silika. Berkala Ilmiah Pertanian 10:1-5.

Ashtiani, F.A., J. Kadir, A. Nasehi, S.R.H. Rahaghi, H. Sajili. 2012. Effect of silicon on rice blast disease. Pertanika J. Trop. Agric. Sci. 35:1-12.
[Balittanah] Balai Penelitian Tanah. 2010. Mengenal silika sebagai unsur hara. Warta Penelitian dan Pengembangan Pertanian 32:19-20.

De Datta, S.K. 1981. Principles and Practices of Rice Production. John Willey and Sons, New York, USA.

Efendi R, M. Azrai. 2010. Identifikasi karakter toleransi cekaman kekeringan berdasarkan respons pertumbuhan dan hasil genotipe jagung. Widyariset $13: 41-50$.

Epstein, E. 2009. Silicon : Its manifold roles in plants. J. Compilation Assoc. Appl. Biol. 155:155-160.

Eviati, Sulaeman. 2009. Petunjuk Teknis Edisi 2. Analisis Kimia Tanah, Tanaman, Air, dan Pupuk. Balai Penelitian Tanah, Bogor, INA.

Fageria, N.K. 2014. Mineral Nutrition of Rice. CRC Press, Danvers, USA.

Gerami, M., F. Allahyar, R.K.M. Mohammad. 2012. Study of potassium and sodium silicate on the morphological and chlorophyll content on the rice plant in pot experiment (Oryza sativa L.). IJACS J. 10:658-661.

Ghanbari, A., Malidareh. 2011. Silicon application and nitrogen on yield and yield components in rice (Oryza sativa L.) in two irrigation systems. International J. Biol. Biomolec. Agric. Food Biotechnol. Engineering 5:40-47. 
Hayasaka, T., H. Fujii, K. Ishiguro. 2008. The role of silicon in preventing appressorial penetration by the rice blast fungus. Phytopathology 98:1038-1044.

Junior, L.A.Z., R.L.F. Fontes, J.C.L. Neves, G.H. Korndorfer, V.T. Avila. 2010. Rice grown in nutrient solution with doses of manganese and silicon. Rev. Bras. Cienc. Solo. 34:1629-1639.

Lindsay, W.L. 1979. Chemical Equilibria in Soils. John Wiley and Sons, New York, USA.

Lu, C., H. Ning, K. Yao, S.J. Xia, Q. Qi. 2010. Plant type and its effects on canopy structure at heading stage in various ecological areas for a two-line hybrid rice combination. Rice Sci. 17:235-242.

Matichenkov, V.V., E.A. Bocharnikova. 2001. Silicon in Agriculture. Datnoff, L.E., G.H. Srryder, G.H. Korndofer, (Eds.). Elsevier Science, Amsterdam 8:209-219.

Matlou, M.C. 2006. A comparison of soil and foliar applied silicon on nutrient avaibility and plant growth and soil applied silicon on phosphorus availability. Thesis. University of Kwazulu-natal, Pietermaritzburg.

Prasetyo, T.B., Y. Syafrimen, Y. Edri. 2010. Pengaruh pemberian abu batubara sebagai sumber silika $(\mathrm{Si})$ bagi pertumbuhan dan produksi tanaman padi (Oryza sativa L.). Solum 7:1-6.

Purwaningsih, H., T.T. Irawadi, Z.A. Mas'ud, A.M. Fauzi. 2012. Rekayasa biopolymer jerami padi dengan teknik kopolimerisasi cangkok dan taut silang. Valensi 2:489-500.

Rao, G.B., P. Susmitha. 2017. Silicon uptake, transportation, and accumulation in rice. J. Pharmacog. Phytochem. 6:290-293

Rodrigues, F.A., L.E. Datnoff. 2015. Silicon and Plant Disease. Springer International publ., Switzerland.

Sacala, E. 2009. Role of silicon in plant resistance to water stress. J. Elementol. 14:619-630.

Wahyuti, T.B., B.S. Purwoko, A. Junaedi, Sugiyanta, B. Abdullah. 2013. Hubungan karakter daun dengan hasil padi varietas unggul. J. Agron. Indonesia 41:181-187.

Wang, W., Z. Yu, W. Zhang, Q. Shao, Y. Zhang, Y. Luo, X. Jiao, J. Xu. 2014. Responses of rice yield. irrigation water requirement and water use efficiency to climate change in China: Historical simulation and future projections. Agric. Water Manag. 146:249-261.

Yohana, O. 2013. Pemberian bahan silika pada tanah sawah berkadar $\mathrm{P}$ total tinggi untuk memperbaiki ketersediaan $\mathrm{P}$ dan $\mathrm{Si}$ tanah, pertumbuhan dan produksi padi (Oryza sativa L.). Agroekoteknologi $1: 1-9$.

Zulputra, Wawan, Nelvia. 2014. Respon padi gogo (Oryza sativa L.) terhadap pemberian silikat dan pupuk fosfat pada tanah ultisol. J. Agroteknologi 4:1-10. 